\title{
Development of Future Managers' Resilience as a Condition for Efficiency and Reliability of Management Activities
}

\author{
Volodymyr Kravets ${ }^{1}$, Halyna Meshko ${ }^{1 *}$, Oleksandr Meshko ${ }^{1}$, Alina Leskiw ${ }^{2}$, and Nataliia Habrusieva ${ }^{3}$ \\ ${ }^{1}$ Ternopil Volodymyr Hnatiuk National Pedagogical University, Ukraine \\ ${ }^{2}$ Bronisław Markiewicz State Higher School of Technology and Economics in Jarosław, Poland \\ ${ }^{3}$ Ternopil Ivan Puluj National Technical University, Ukraine
}

\begin{abstract}
The article is devoted to the study of the future managers' resilience development problem at the stage of Master's training. The state of development of the specified problem in psychological scientific literature and practice was analyzed. The essential approaches to interpreting resilience were clarified and the factors of resilience, considering the analysis of the scientific literature, were analyzed. The method of determining neuropsychological resilience, the risk of maladaptation in stress "Prognosis", adapted method of L. Wasserman "Diagnosis of neuroticism" and SACS-questionnaire and models of coping behavior, developed by S. Hobfoll, were used to measure the ability to maintain psychosocial adaptation during stress and to diagnose the level of neuroticism, neuropsychological resilience to stress. The results of the study served as a basis for finding alternative ways of developing future managers' resilience. The program of future managers' resilience development, focused on the formation of productive interaction and constructive overcoming the professional difficulties skills; mastering constructive coping strategies; learning methods and technics of self-regulation; formation of assertive behavior and positive thinking, selfefficacy of the individual, was substantiated and developed. The main ways of the offered resilience development program's realization were outlined. The role of the course "Occupational Health" in the development of future managers' resilience was developed and characterized.
\end{abstract}

\section{Introduction}

New requirements to the manager's personality constantly appear under the current conditions of development, reform, and modernization of society, the rapid leap into the new reality of quarantine restrictions because of coronavirus infection. A modern manager needs the ability to adapt to rapid changes in living conditions. He needs the skills and qualities necessary to work in new realities, distant work technologies, virtual communications, distant team management, etc. A manager needs something that gives psychological strength to hold on and withstand the challenges of modern society, constructively overcome life and professional difficulties, recover from stress. Therefore, the basis of quality life and successful management is high-stress resistance and resilience. They help to adapt more easily to changes, increase the level of viability of the manager, and contribute to the preservation of team spirit and the formation of a favorable sociopsychological climate of the organization.

Stress resistance is one of the personality traits that ensures the success of overcoming professional stress. Stress resistance determines how long a specialist can be in an uncomfortable environment without harm to physical and mental health. Stress resistance helps the specialist to protect his personality from disintegration; various disorders create a basis for inner harmony, high efficiency, and determines the state of his professional health [1].

If stress resistance means how easily we can cope with stress, resilience depends on how quickly we can get back in shape after the stress and at what time we can maintain a positive psychological attitude. Resilience is a person's ability to cope with difficult life events and recover from difficulties or stress [2]. Therefore, it is extremely important to develop such a quality of a specialist as resilience, which allows to overcome the negative consequences of encountering adverse circumstances and serious professional difficulties, to prevent destructive behavior, to ensure the quality of further life and professional activity.

It is important to develop both stress resistance and resilience simultaneously and in unity, because a specialist will be able to quickly deal with stressors, but will "go away" for a long time, or recover quickly from stress, but when you meet a new stressor again experience a destructive surge of emotions.

All this actualizes the professional stress resistance and resilience formation problem of the future managers at the stage of education in a higher education institution during the Master's training in particular. Our previous research was devoted to the problem of future heads' of educational institutions' professional stress resistance formation. [3].

\section{Literature review}

\footnotetext{
* Corresponding author: hal-meshko@ukr.net
} 
Modern science developed a significant arsenal of tools for managing stressful situations, ways to optimize functional states, methods of preventing negative emotional states $[4,5,6]$. But research is mainly aimed at preventing the occurrence of stress in professionals, increasing the level of their stress resistance. Insufficient attention is paid to the formation of stress resistance and resilience of future professionals. The possibilities and ways of developing resilience in future managers are unexplored.

In the scientific literature, the terms "psychological resilience", "stress resistance", "stress resistance", "stress tolerance", "frustrating tolerance", "viability", and "viability" are used as synonyms for resilience.

Stress resistance is understood as a structuralfunctional, dynamic, integrative property of personality and the result of the transactional process of collision of an individual with a stress factor, including selfregulation, cognitive representation, objective characteristics of the situation, requirements to personality [4, p.74] Stress resistance provides the ability to carry out professional activities, withstand significant intellectual, volitional and emotional stress in stressful conditions while maintaining a state of psychophysical balance and avoiding the consequences of harmful effects on activities and their own health. Indicators of stress resistance are emotional stability, self-control, self-regulation, psychological stability, frustration tolerance [5, p.27].

The concept of resilience was empirically discovered more than 40 years ago. The term "resilience" in psychological, scientific terminology was introduced in the works of E. Werner and R. Smith [7]. In the scientific literature, personality quality and resilience are interpreted as the ability to maintain resilience to external and internal threats without losing the pace of development. [8, p.160]. Resilience is a dynamic process that involves positive adaptation in the context of significant problems [9].

O. Khominich [8] analyzes the approaches to defining the concept of "resilience" in domestic and foreign psychology, understanding this phenomenon as a property of the individual and as overcoming stress. The scientist proposes to use the concept of "resilience" in domestic psychology to denote a dynamic process in the contexts of adaptation and self-regulation.

The term "resilience" is generally associated with the ability of the psyche to recover from adverse conditions [10]. Resilience plays an important role in the ability and formation of post-traumatic personality growth [11]. Highly resilient individuals have strong coping skills, but they cannot cope with the psychological consequences of trauma. They also do not have the inner motivation to feel new experiences, which brings many new opportunities for personal change, which offers the most traumatic situation with its emotional tension. [12].

In a study by G. Lazos, [13] the data of modern scientific researches concerning the resilient qualities of the person were analyzed. The scientist substantiated and developed a theoretical and methodological model of psychotechnics of resilience development and proposed the structure of a theoretical model of resilience through its main constructs risk factors, protective factors, and vulnerability factors.

Scientists focus on the diagnosis of both the general level of resilience and protective (resilient) factors, resources, competencies, the developed psychotechnics of influence. In his article, [13] G. Lazos gives examples of effective psychotechnologies of development and formation of resilient personality traits. Most of the psychotechnics are based on a combination of different psychotherapeutic methods and technics. Modern resilience psychotechnologies include spiritual practices, physical procedures, recommendations for maintaining and promoting health, and so on.

The purpose of the research is to identify and analyze opportunities and ways to develop resilience in future managers at the stage of the Master's degree. The purpose of the study was specified in the following tasks: 1) to determine the state of development of the problem of development of resilience of future professionals; 2) to diagnose the formation of resilient personality traits of the future manager; 3) taking into account the results of diagnostics to develop a program for the development of resilience of future managers at the stage of master's degree.

\section{Research methodology}

The model of resilience proposed by G. Lazos is important for our study [13], comprising four separate phases: a confrontation with risk factors (with traumatic events); activation of protective factors and vulnerabilities; the interaction between protective factors and vulnerabilities; creating resilience or going into a maladaptation.

In research, works devoted to the study of factors influencing the development of resilience are of interest. In the scientific literature, there are factors that affect resilience: a friendly attitude to themselves and their abilities; ability to make realistic plans and implement them; development of communication skills, in particular, assertiveness (this is the ability to defend oneself in a polite and friendly way, to express one's feelings and thoughts without offending or violating the dignity of other people); nurturing values and planning life according to them; development of own "support system": meaningful and deep relations with close people, with nature, with God, and also with itself; nurturing hope; developing the ability to solve problems [2].

Foreign scientist A. Masten [14] created a list of resilient factors and corresponding adaptive systems: effective holding in childhood and the quality of education; close relationships with other adults; the presence of close friends and romantic partners; intellectual development and problem-solving skills; self-control, emotion regulation, planning; motivation for success, personal effectiveness; faith, hope, meaning of life; effective training; efficiency in relations with neighbors, colleagues.

Positive thinking plays an important role in the development of resilience. Positive thinking helps you to 
manage difficult, conflict situations and your efforts to resolve them. M. Moltz calls positive thinking a universal intellectual tool, the essence of which is to strengthen the positive image of one's "I" through successful deeds and actions and not does not allow it to deteriorate or collapse in case of failures or mistakes in behaviour, activities, life [15]. The scientist names two main reasons why the image of one's own "I" is the key to a successful life: 1) all actions, feelings, deeds, even abilities are consistent with the image of one's own "I" through unconscious and conscious mechanisms of selfregulation; 2) if the holistic image of one's own "I" changes, then life and professional problems, including complex, stressful, traumatic ones, which are consistent with this new image, are solved much easier, without undue effort. Therefore, M. Moltz recommends the formation of positive thinking, starting with the search for oneself, with their own self-acceptance and adequate self-esteem. It is also important to study the principles of positive thinking and constantly adhere to them, change your worldview, a worldview toward optimism for positive thinking to become a way of life and activity.

The growth of such personal formations as intelligence, reflection, self-attitude, motivation to succeed, self-efficacy, will contribute to achieving a high level of formation of positive thinking [16, 17]. Therefore, the development of positive thinking of future managers involves the formation of a creative attitude to management, the ability to find joy in achievements, insignificant successes and achievements, conscious control of their thoughts and emotions, strengthening faith in their own strengths, capabilities, success, the ability to be optimistic in life and professional situations, even complex and extreme.

The technology of changing the self-concept and forming positive thinking, developed by V. Kaloshin, is important for our research. It involves the following stages: awareness of the need and possibility of a positive self-concept; relaxation; subconscious programming (change of self-concept); repeat the last two stages over a period of time (at least 21 days) [18]. A similar approach is presented in the work of B. Tracy, which proposes a five-element (five-stage) process of gaining strength to become highly effective, positive thinking: the idea of the ideal $\rightarrow$ translation into a verbal form $\rightarrow$ visual representation $\rightarrow$ emotional perception $\rightarrow$ implementation [17].

Creating a program for the development of resilience S. Osborn [19] suggested focusing on the targets of psychological / psychotherapeutic interventions to enhance human resources to promote resilience to life's problems, rather than focusing on and exploring their conditions (post-traumatic stress disorder, exhaustion, burnout, etc.). This provision was the basis for the development of a program for the development of resilience of future managers and served as a guide for the content of training practice.

To identify opportunities and ways to develop the resilience of future managers, to develop a program for the development of resilience of future managers at the stage of Master's degree, it is important to diagnose the formation of resilient personality traits of the future manager.

\section{Research methods}

To diagnose the level of the neuroticism of the personality of future managers, neuropsychological stability in stress, the ability to maintain psychosocial adaptation during stress we used: adapted method of L. Wasserman "Diagnosis of the level of neuroticism" [20, p.193 -194]; method of determining neuropsychological stability, the risk of maladaptation in stress "Prognosis" [20, p.195-198]; questionnaire of SACS-strategy and model of coping behavior, developed by S. Hobfoll [20, p.230-238]. 84 applicants for higher education were involved in the study of the second (master's) level of specialty: 073 Management of Volodymyr Hnatiuk Ternopil National Pedagogical University and Ivan Franko Drohobych State Pedagogical University (Ukraine).

The results of the study formed the basis for the development of a program for the development of resilience in future managers.

Adapted method of L. Wasserman "Diagnosis of the level of neuroticism" [20, p.193-194] provides answers "yes" or "no" to each of the 30 judgments. The more positive responses received, the higher the level of the neuroticism of the individual.

The use of the method "Determination of neuropsychological stability, the risk of maladaptation in stress" Prognosis " [20, p.195-198] requires a "yes" or "no" answer to each of the 84 statements. The number of correct answers, according to the key, was counted. The higher the number of points scored, the higher the level of neuropsychiatric instability. The obtained points correlate with the conditional scale of neuropsychological stability. The higher the points on the conditional scale, the higher the level of neuropsychological stability and the lower risk of maladaptation under stress. The methodology contains a scale for checking the sincerity of the answers, which allows determining the reliability of the results.

Questionnaire SACS-strategy and model of coping behavior, developed by S. Hobfoll [20, p.230-238] contains 9 subscales, each of which reflects a particular model of behavior in a complex (stressful) situation. Respondents were asked to choose the answer ("no, not at all", "yes, quite right", "difficult to answer", "rather no than yes", "rather yes than no") to 54 statements that characterize their behavior in a difficult (stressful) situation. When calculating the results of the survey, we use a key for the representatives of communicative professions, which makes it possible to identify the predominance of one or another model of behavior in a tense (stressful) situation.

\section{Research results}

The results of our study using the method of determining neuropsychological stability, the risk of maladaptation in stress "Prognosis" indicate a significant percentage of 
future professionals (38.1\%) with a low level of neuropsychological stability and a high risk of maladaptation in stress (figure 1).

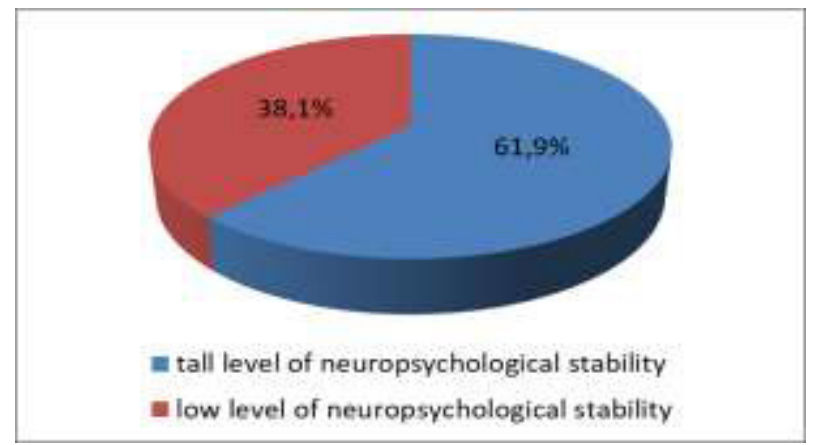

Fig. 1. The results of our study using the method of determining neuropsychological stability, the risk of maladaptation in stress "Prognosis".

Using the adapted method of L. Wasserman "Diagnosis of the level of neuroticism" [20, p.193-194] made it possible to identify the predominance of future managers with an average level of neuroticism $(52.4 \%$ of respondents). The low level of neuroticism, which is characteristic of $25.1 \%$ of respondents, shows emotional stability, a positive background of feelings (calm, optimism), initiative, self-esteem and self-sufficiency, independence and social courage, ease of communication. While the high level of neuroticism, found in $22.5 \%$ of respondents, is evidence of pronounced emotional excitability, lack of initiative and passivity, egocentric personal orientation, communication difficulties, increased susceptibility to mental tension and stress (figure 2).

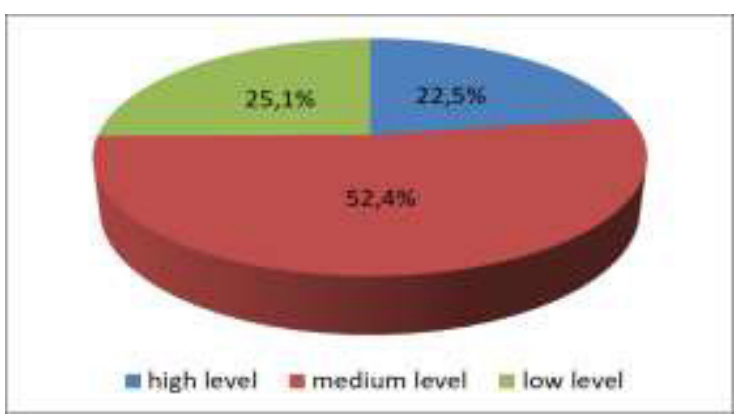

Fig. 2. Distribution of future managers by level of neuroticism.

Research using the SACS-strategy questionnaire and coping behavior model [20, p.232-234] made it possible to diagnose the predominance of unconstructive models of behavior of future managers in a stressful situation.

The results of the study show that undergraduates have a small number of constructive models of overcoming stressful situations, which is expressed in low rates of assertive behavior (dominated by $2.4 \%$ of respondents), entering into social contact (11.9\%), seeking social support $(14.3 \%)$, in higher rates of caution (predominant in $16.7 \%$ of respondents), aggressive (19.04\%) and manipulative actions (26.2\%). Impulsive actions are typical actions for $2.4 \%$ of respondents, avoidance $-4.8 \%$. antisocial $-2.4 \%$ (figure 3).

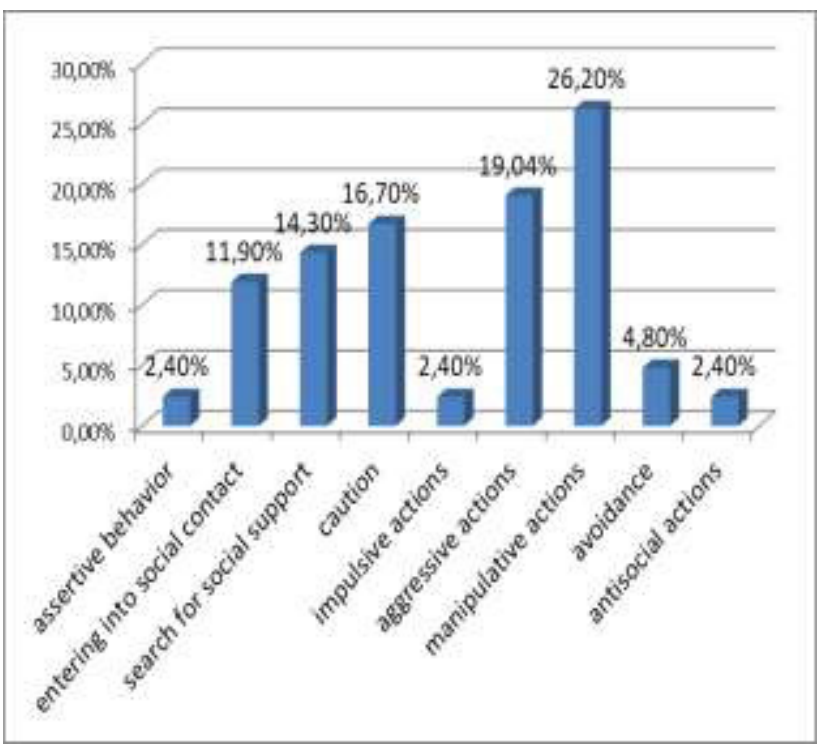

Fig. 3. The predominance of behavior patterns of future managers in a stressful situation.

Coping helps maintain psychosocial adaptation during stress or in difficult situations. Studies show that "successful" managers differ from "unsuccessful" by more different models of overcoming difficult (stressful) situations. High rates of assertive behavior, social contact, and social support, and low rates of aggressive and antisocial behavior [21]. Models of their behavior are characterized by activity, prosociality, and flexibility. For "unsuccessful" managers, these figures are just the opposite [21].

\section{Discussion}

The results of diagnosing the level of personality neuroticism, neuropsychological resilience in stress, the ability to maintain psychosocial adaptation during stress give grounds for concluding the low level of formation of resilient qualities of future managers and the need and assumptions about the possibility of targeted influence on students' resilience development on the stage of their Master education in a higher education institution.

Taking into account everything that was mentioned above, the program of resilience of future managers was developed by us, which involves (figure 4, 5): 


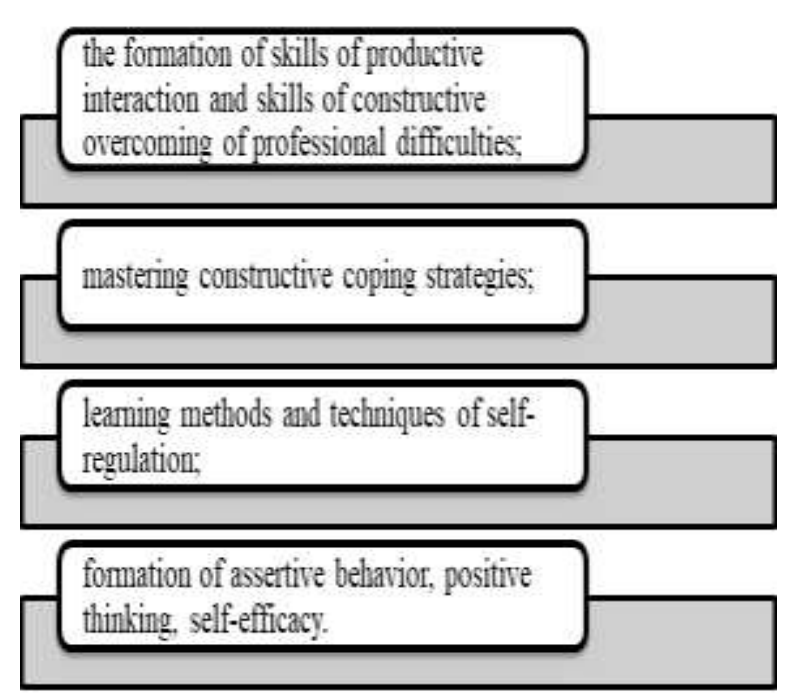

Fig. 4. Program of development of resilience of future managers.

The development of resilience of future professionals involves the elimination of potential sources of stress and neurotic components in their internal and strengthening resources that will contribute to resilience to life's difficulties and occupational difficulties.

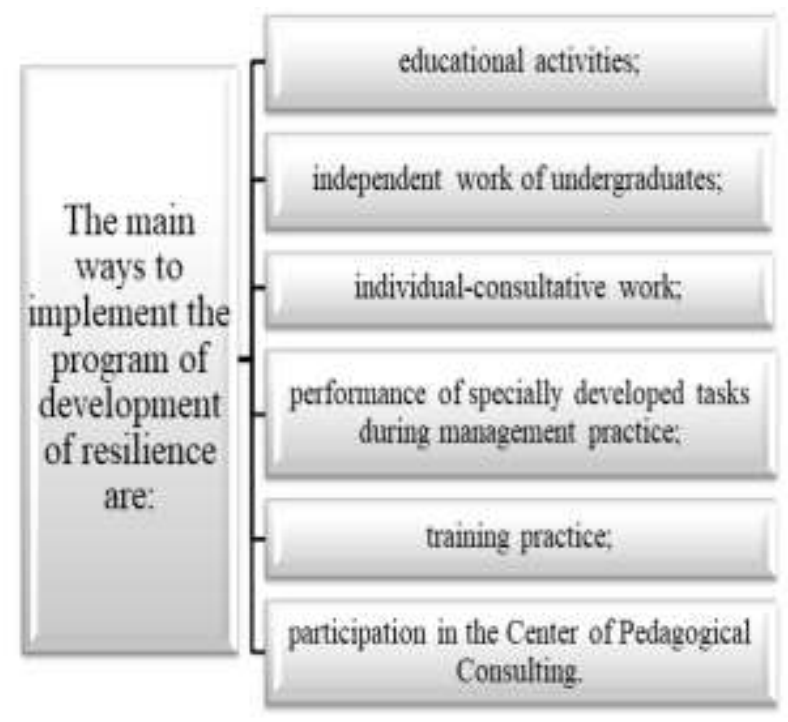

Fig. 5. The main ways to implement a resilience development program.

The course "Occupational Health" developed by us is directed on the formation of competence of health care, professional stress resistance, and development of resilience of undergraduates [22]. The objectives of the course are: mastering by undergraduates a system of knowledge about the essence of occupational health, its criteria, determinants; mastering the basics of stress management in management; mastering modern health technologies, psychotechnologies of self-healing, technologies of self-rehabilitation; motivation to find their own systems of recovery and harmonization of their own inner world [22].

The course "Occupational Health" (3 ECTS credits, 10 hours of lectures, 20 hours of practical classes) contains two content modules: "Occupational health as a condition for effective management" and "Ways and means to preserve and enhance occupational health". Fundamentals of professional self-rehabilitation ". The program of the course includes the study of the following topics:" Determinants of occupational health"; "The impact of the profession on the health of the manager. Professional deformations, destructions, ways of their prevention and elimination"; "Occupational stress. Emotional burnout"; "Stress management in management. Methods of formation of professional stress resistance"; "Orthobiotics in professional activities"; "Harmony of personality and professional health"; "Technologies for maintaining and strengthening occupational health. Occupational selfrehabilitation. Psychotechnologies of self-healing» [22].

In the process of studying this course, future managers perform several tasks aimed at the formation of health competence and the development of their resilient qualities:

1. Create a "Manager's Occupational Health Code".

2. Make two "Memo for the manager" (optional): Psychotherapist yourself! How exactly ?; Recipes for mental balance; Occupational stress medication; How to protect yourself from professional stress; How to deal with "erosion of the soul"; How not to burn in the flames of the profession; How to become a self-effective person; The path to assertive behaviour; How to get rid of thinking "red pencil". How to overcome professional difficulties with the least loss of health, Professional longevity: the path to it.

3. Prepare an essay on one of the proposed topics: a) Laws of the reasonable lifestyle of the manager; b) Constructive overcoming of professional difficulties; c) Constructive and destructive reactions to failure and occupational health; d) Positive thinking, sanogenic thinking: two sides of the same problem; e) Sanogenic potential of the individual, positive mental position, their activation in difficult situations of professional activity. Professional achievement stress and workaholism; Coping strategies in management.

4. To identify their own problems, external and internal resources to maintain and strengthen their health based on the results of self-observation, self-diagnosis, testing the level of stress resistance, the tendency to emotional burnout, level of neuroticism, level of anxiety, etc.. To develop an individual program for maintaining and strengthening occupational health. To analyze internal reserves and external conditions that will facilitate its implementation.

5. To create a portfolio on the problems of maintaining and strengthening the manager's professional health.

6. To develop and present projects "Own self-healing system" and "Manager's psychological first aid kit" and other tasks.

We have also developed and implemented an antistress training program [23]. The major tasks of antistressing are aimed at launching self-concept, constructive communication, and self-regulation of stress, positive thinking. The activities of the training group are aimed at the formation of reflection, the ability to recognize their emotional state, motives, 
consequences of actions; positive perception of oneself and acceptance of oneself, one's strengths and weaknesses, assertive behavior; activation of psychological mechanisms of self-regulation, development of readiness for self-changes and selfdevelopment, the formation of skills to find own resources in difficult situations.

The activity of the training group involves the actualization of personal and neuro-psychological resources of its members, including active strategies for overcoming behavior, awareness and reduction of the destructive influence of accentuations and temperament, resolution of interpersonal conflicts. Future managers learn to model behavior in stressful situations, understand their own emotions, and use different psychotechnics to focus on the positive.

The participation of future managers in the work of the training group contributes to the knowledge of their strengths and weaknesses, the gradual elimination of neurotic components of their own inner world, improving interaction with other people. The training creates conditions for the development of such qualities as communicativeness, reflexivity, assertiveness, tolerance, and mastering of subjective self-influence by psychotechnics. Introspection during the training allows to separate negative emotional reactions from negative habitual patterns of self-destructive behavior that destroys health, reduces the degree of emotional negative reaction to situational influences.

During the management practice, undergraduates perform specially designed tasks aimed at developing the ability to adequately assess their own strategy of behavior in a difficult situation, the ability to diagnose the level of self-regulation, the level of neuropsychological stability, and susceptibility to stress, ability to overcome professional difficulties. Students test the effectiveness of developed programs for the preservation of professional health, in particular, the ways of regulating the emotional state, relaxing emotional stress, removing fatigue, achieving mental equilibrium.

It should be noted that in the program of development of resilience, an important place is given to individual psychodiagnostic and psychocorrective conversations-consultations with undergraduates. They are held at the Center of Pedagogical Consulting [24]. Such conversations-consultations help to identify personal resources of stress resistance and resilience, the causes of destructive behavior in conflict and difficult situations, the causes of pathogenic thinking, insecure behavior.

The Center's of pedagogical consulting activities are focused on the diagnosis of individual-typological and personal characteristics of undergraduates, their interpretation, assistance in finding resources of resilience and selection of constructive coping strategies, assistance in mastering methods of professional stress management, mastering stress management. Master's student's training, webinars, masterclasses, round tables are held within the functioning of the Center of pedagogical consulting. [24,25].

\section{Conclusions}

Thus, resilience is an important factor in ensuring the efficiency and reliability of management. Diagnosis of the level of the neuroticism of future managers, neuropsychological resilience in stress, the ability to maintain psychosocial adaptation during stress, confirmed the need for the formation of their resilience at the stage of a Master's degree in higher education.

For the development of resilience of future managers: the formation of skills of productive interaction and constructive overcoming of professional difficulties, the formation of strategies to protect against stress, learning methods, and technics of self-regulation, the formation of positive sanogenic thinking are important.

The main ways of realization of the offered program of development of resilience are outlined: educational activity, independent work of undergraduates, individual consultative work, training practice, performing specially developed tasks during administrative practice, participation in the activity of the Center of pedagogical consulting.

The proposed program of resilience development is focused on strengthening the resources of the personality of the future specialist, which will contribute to their resilience to life's troubles and professional difficulties. Our course "Professional Health" and anti-stress training played an important role in future managers' resilience development.

Availability of acmeological educational environment in the institution of higher education and maturity of lecturers' acme-synergetic position are prerequisites for the implementation of the programme for the development of resilience of future managers. The lecturers developing the resilient qualities of the students must be the embodiment of the standards themselves; otherwise, the goals are not just failed, but the opposite result may be achieved.

We see the prospects for further scientific research in testing the effectiveness of the developed program for the development of resilience, justification, and development of technologies for the formation of the resilience of future managers in the digital space of formal and non-formal education.

\section{References}

1. H. Meshko, O. Meshko, N. Drobyk, O.

Mikheienko, Psycho-pedagogical training as a mean of forming the occupational stress resistance of future teachers. Proc. of the ICSF 2020, Kryvyi Rih, Ukraine, May 20-22, 2020. E3S Web of Conferences 166 (2020), https://www.e3sconferences.org/articles/e3sconf/abs/2020/26/e3scon f_icsf2020_10023/e3sconf_icsf2020_10023.htm.

Accessed $\overline{26}$ January 2021

2. Ed. S. Bozhyk, Yak plekaty u sobi rezylientnist ta chomu tse vazhlyvo? (How to cultivate resilience and why is it important?) (Fizis: Psychological literacy, Lifestyle, 2020), https://fizis.net/psyhologichna-gramotnist/iak- 
plekaty-u-sobi-rezylientnist-ta-chomu-tse-vazhlyvo. Accessed 26 January 2021

3. G.M. Meshko, O.I. Meshko, Formuvannia profesiinoi stresostiikosti maibutnikh kerivnykiv zakladiv osvity na etapi mahisterskoi pidhotovky (Formation of professional stress resistance of future heads of educational institutions at the stage of Master's training). Humanitarium $\mathbf{4 3}$ Issue 1: Psychology (2019), pp. 103-112. doi: 10.31470/2308-5126-2019-43-1-103-112

4. V. Korolchuk, Dissertation, Psykholohiia stresostiikosti osobystosti (Psychology of stress resistance of the person) Institute of Psychology G.S. Kostyuk Academy of Pedagogical Sciences of Ukraine (Kyiv, 2009), p.513

5. Kudinova M.S. Porivnialnyi analiz poniat «stresostiikist» ta «emotsiina stiikist» (Comparative analysis of the concepts of "stress resistance" and "emotional stability"). Theory and practice of modern psychology 1 (2016), pp. 22-28

6. W. Pilecka, Odporność psychiczna jako wyznacznik zdrowia, eds. by H. Wrona-Polanska and J. Mastalski. Promocja zdrowia (Krakow, Wydawnictwo Uniwersytetu Jagiellonskiego, 2009), pp. 109-122

7. E. Werner, R. Smith, Overcoming the odds: high risk children from birth to adulthood (Ithaca, New York, Cornell University Press, 1992)

8. O.M. Khaminich, Rezilientnist: zhyttiestiikist, zhyttiezdatnist abo rezilientnist? (Resilience: viability, viability or resilience?) Scientific Bulletin of Kherson State University. Series: Psychological sciences 6 T. 2 (2016), pp.160-165

9. D. Fletcher, M. Sarkar, Review of Psychological Resilience. European Psychologist 18 (2013), pp. 12-23 https://www.researchgate.net/publication/26365150 6. Accessed 26 January 2021

10. A. Borucka, Koncepcja resilience. Podstawowe zatożenia i nurty badań, ed. W. Junik. Resilience (Warszawa, Parpamedia, 2011), pp. 11-28

11. G.P. Lazos, Posttravmatychne zrostannia: teoretychni modeli, perspektyvy dlia praktyky (Posttraumatic growth: theoretical models, new prospects for practice) Current problems of psychology 1 Issue: 45 (2016), pp. 120-127

12. R.G. Tedeschi, L.G. Calhoun, Posttraumatic growth: Conceptual foundations and empirical evidence Psychological Inquiry 15 ( 2004), pp. 1-18

13. Lazos G.P., Teoretyko-metodolohichna model rezylientnosti yak osnova pobudovy psykhotekhnolohii yii rozvytku (Theoretical and methodological model of resilience as a basis for constructing psychotechnology of its development) Organizational psychology. Economic psychology 2-3 (17) (2019), pp.77-89 doi: https://doi.org/10.31108/2.2019.3.17.9
14. A. Masten, Ordinary magic: resilience in development (New York, The Gulford press, 2014)

15. Molts M. Y., - eto Ya, ili Kak stat schastlyvym (it is Me, or How to become happy) (Moskva, Mysl, 1994), pp. 192

16. Pil N.V. Udivitielnyie riezultaty pozitivnoho myshleniia (Amazing Results of Positive Thinking) (Mynsk, OOO «Popurry», 2003), pp. 320

17. Treisi B., Izmieni myshlieniie - i ty izmienish svoiu zhizn (Change your thinking - and you change your life), 2nd edn. (Minsk, «Popurri», 2006), pp.384

18. Kaloshyn V.F., Yak sformuvaty pozytyvne myslennia (How to form positive thinking) Praktychna psykholohiia ta sotsialna robota 3. (1998), p. 27

19. J. Osborn, Seven salutary suggestions for counsellor stamina Journal of Counselling \& Development 82 (2004), pp. 354-364

20. B.A. Smirnov, E.V. Dolgopolova, Psykholohiia deiatelnosti v ekstremalnykh sytuatsiakh (Psychology of activity in extreme situations), 2nd ed. (Kharkiv, Humanitarian Center, 2007), p. 292

21. G.S. Nikiphorov, M. A. Dmitrieva and V.M.Snetkov (eds.), Praktikum po psikholohii menedzhmenta $i$ profesionalnoi deiatelnosti (Workshop on the psychology of management and professional activity) (SPb., Rech, 2001), p. 448

22. Profesiine zdorovia: elektronnyi navchalnometodychnyi kompleks dystsypliny dlia pidhotovky mahistriv spetsialnosti 073 Menedzhment (Occupational health: electronic educational and methodical complex of discipline for preparation of masters of specialty 073 Management) (Website of the Ternopil Volodymyr Hnatiuk National Pedagogical University), https://elr.tnpu.edu.ua/enrol/index.php?id=1796. Accessed 26 January 2021

23. Antystres-treninh (Antistress training) (Website of the AIPo), http://www.airo.com.ua/antistres-trening. Accessed 26 January 2021

24. Polozhennia pro Tsentr pedahohichnoho konsaltynhu (Regulations on the Center of Pedagogical Consulting) (Website of the Ternopil Volodymyr Hnatiuk National Pedagogical University), http://tnpu.edu.ua/about/public_inform/upload/2020/ Polozhennia_pro_Tsentr_konsaltynhu.pdf. Accessed 26 January 2021

25. Tsentr pedahohichnoho konsaltynhu. Fakultet pedahohiky i psykholohi Ternopilskoho natsionalnoho pedahohichnoho universytetu im. V. Hnatiuka (Center of Pedagogical Consulting. Faculty of Pedagogy and Psychology, Ternopil Volodymyr Hnatiuk National Pedagogical University), http://fpp.tnpu.edu.ua/pidrozdili/centrpedagogichnogo-konsaltingu . Accessed 26 January 2021 